\title{
Studying the Middle East from Brazil: reflections on a different worldview
}

Estudiar el Medio Oriente desde Brasil: reflexiones sobre una cosmovisión diferente

\section{Estudando o Oriente Médio a partir do Brasil: reflexões sobre uma visão de mundo diferente}

Arlene Clemesha'
Silvia Ferabolli²

DOI: 10.5752/P.2317-773X.2020v8.n4.p97

Received in: August 10, 2020

Accepted in: December 07, 2020

\begin{abstract}
This paper describes and analyses the experiences of two Brazilian professors in teaching History and International Relations of the Middle East and the Arab World, both at undergraduate and graduate levels. Essentially, this paper is an exercise of comparison between the limits faced - but also the possibilities found - by the authors in the development of their activities as Latin American professors promoting the study of the Middle East and the Arab World in Brazil. Its main aim is to help scholars involved with these subject-matters to reflect on their pedagogical practices and on the knowledge they are promoting (or inhibiting) with their research proposals and teaching procedures. Anchored in the methodological techniques of participant observation and critical curriculum analysis, this paper reaches the conclusion that the socialisation of Brazilian scholars in the Anglo-Saxon scholarship on the Middle East must be mediated by a critical posture towards any parochial knowledge that pretends to be global. When the critical approach to academic literature is not the case, scholars tend to become more reproducers of the discourses produced in the North about the region than thinkers of the Global South capable of offering their educatees a space of knowledge production that is meaningful to them as Brazilian students.
\end{abstract}

Keywords: Middle East. Arab World. Pedagogy.

\section{RESUMEN}

Este artículo describe y analiza las experiencias de dos docentes brasileños en la enseñanza de Historia y Relaciones Internacionales en el Oriente Medio y el Mundo Árabe, tanto en cursos de pre-grado como de pos-grado. Este artículo, essencialmente, es un ejercicio para comparar los límites enfrentados, pero también las posibilidades encontradas, por los autores en el desarrollo de sus actividades como maestros latinoamericanos que promueven el estudio del Medio Oriente y el mundo árabe en Brasil. Su objetivo principal es ayudar a los 
académicos involucrados en este tema, a reflexionar sobre sus prácticas pedagógicas y sobre el conocimiento que están promoviendo (o inhibiendo) con sus propuestas de investigación y procedimientos de enseñanza. Baseado en las técnicas metodológicas de observación participante y análisis crítico del plan de estudios, este artículo concluye que la socialización de los eruditos brasileños en la literatura anglosajona sobre el Medio Oriente debe estar mediada por una postura crítica hacia cualquier conocimiento parroquial que pretenda ser global. Cuando no se toma tal posición, los académicos pueden volverse más reproductores de los discursos producidos en el Norte sobre la región que pensadores del Sur Global, capaces de ofrecer a sus estudiantes un espacio para la producción de conocimiento que sea significativo para ellos como estudiantes brasileños.

Palabras clave: Oriente Medio. Mundo Árabe. Pedagogía.

\section{RESUMO}

Este artigo descreve e analisa as experiências de duas professoras brasileiras no ensino de História e Relações Internacionais do Oriente Médio e do Mundo Árabe, tanto na graduação quanto na pós-graduação. Essencialmente, este artigo é um exercício de comparação entre os limites enfrentados - mas também as possibilidades encontradas - pelas autoras no desenvolvimento de suas atividades como professoras latino-americanas promovendo o estudo do Oriente Médio e do Mundo Árabe no Brasil. Seu principal objetivo é auxiliar os acadêmicos envolvidos com essa temática a refletir sobre suas práticas pedagógicas e sobre o conhecimento que estão promovendo (ou inibindo) com suas propostas de pesquisa e procedimentos de ensino. Ancorado nas técnicas metodológicas da observação participante e da análise crítica do currículo, este artigo conclui que a socialização de estudiosos brasileiros na literatura anglo-saxônica sobre o Oriente Médio deve ser mediada por uma postura crítica em relação a qualquer conhecimento paroquial que se pretenda ser global. Quando tal posicionamento não é assumido, os acadêmicos podem se tornar mais reprodutores dos discursos produzidos no Norte sobre a região do que pensadores do Sul Global capazes de oferecer a seus educandos um espaço de produção de conhecimento que seja significativo para eles como estudantes brasileiros.

Palavras-chave: Oriente Médio. Mundo Árabe. Pedagogia.
3. The Arabic term means "place of immigration", and was used to name the literary movement created by Arab immigrants in the Americas during the first half of the 20th century.
"In everything different from each other, nothing could cloud the friendship of the two Turks, the Syrian and the Lebanese - they were of fraternal and enemy nationalities".

Postface by José Saramago to the novel by Jorge Amado, The discovery of America by the Turks (1994)

Introduction

The teaching and scholarly research of themes related to the peoples that have been called "Turks" in Latin America in general, and in Brazil in particular, is a relatively recent albeit rapidly developing field in universities throughout the region. In the main Brazilian universities, Arabic language and literature were the first programs to be established. They benefited from the strong Arab immigration to the region and the important mahjar ${ }^{3}$ literature developed in the first half of the twentieth century, following the arrival in Brazil of many Arab immigrants with Ottoman passports, who were therefore called "Turks".

Several decades later, the language and literature programs were followed by the implementation of undergraduate courses and graduate 
research lines in History, Anthropology, Political Science and International Relations. They were dedicated to Arab, Muslim, Turkish/Ottoman and Persian/Iranian studies, usually - but not exclusively - grouped under the great "Middle East" umbrella. The development of these courses has encountered important limitations, but also marked advantages. Firstly, these disciplines and research programs can be implemented together with the critique of Orientalism itself. Secondly, there exists a large potential for the exchange of experiences and knowledge between regions - the Middle East and Latin America - that are in dialogue with each other on the bases of comparable historical and political conditions (CLEMESHA, 2016).

This paper proposes an approach to Middle Eastern studies that focuses on less ethnocentric theoretical and analytical methods and perspectives and from a worldview that both avoids the essentialization of the peoples and societies of the region and recognizes the uniqueness of their historical, political, social, and cultural developments. To achieve this goal, the authors describe and analyze their experiences in undergraduate and graduate teaching of courses whose central theme is the Middle East and/or or the Arab World, two concepts that are often used as synonyms, but that have specifics that need to be discussed, if what is sought is a differentiated view of these regions. While the Middle East is an analytical category that describes a region that even today "no one knows" where it is, in the words of Roderic Davison in 1960 (DAVISON, 1960), the Arab World is the physical and ideational space constituted by the twenty-two members of the League of Arab States and its diasporas. While the Middle East is built by the external gaze of scholars who define its borders according to their teaching and research interests, the Arab World was - and has been - engendered by a historical process centred around the idea that those who speak Arabic and/or identify themselves as Arabs form a "diverse unit" and that the political, social, economic, and especially cultural dynamics that unite them - even in diversity - deserve a differentiated academic-intellectual engagement (FERABOLLI, 2015).

In order to promote this necessary dialogue, this study employs participant observation and critical curriculum analysis as its main methodological techniques. The paper is divided as follows: the first section is dedicated to the analysis of teaching and learning Arab and Middle Eastern studies in the Graduate Program in International Strategic Studies (PPGEEI) of the Federal University of Rio Grande do Sul (UFRGS) and in the undergraduate course in International Relations of the same university. The second section follows the same undertaking, but focusing on the field of Arab History at the Arabic Language, Literature and Culture course of the Department of Oriental Letters of the Faculty of Philosophy, Letters and Human Sciences (FFLCH) of the University of São Paulo (USP). Essentially, this paper is an exercise of comparison between the limits faced - but also the possibilities found - by the authors in the development of their activities as Latin American professors promoting the study of the Middle East and the Arab World in Brazil. Its main aim is to offer productive insights in order to help scholars involved with these subject-matters to also reflect on their pedagogical practices and on the knowledge they are promoting (or inhibiting) with their research proposals and teaching techniques. 
A 2017 quantitative and qualitative research piece focusing on the Brazilian academic research on the Middle East, found that the University of São Paulo (USP) and the Federal University of Rio Grande do SUL (UFRGS) had produced the largest amount of theses and dissertations in the past decades on this study area. From 1996 to 2017, USP produced 100 thesis and dissertations related to Arabic or Middle Eastern topics, while UFRGS produced 18, followed closely by UNICAMP, with 17, UFSC with 13, PUCSP, with 13, UFPR with 12 , UNB with 12 , and so forth, totaling 266 works defended at Brazilian universities during that period. While the academic research produced at USP tended to concentrate on Arabic and culture related topics, with a lesser amount of research on International Relations, the contrary could be observed in regard to UFRGS, and other federal universities where the Middle Eastern studies were implemented more recently and typically in the International Relations courses. Therefore, the universities and programs chosen for this study hold very distinct realities in regard to when and how these programs were implemented. Notwithstanding, they currently face similar theoretical and methodological challenges, which allow them to be analysed in parallel and comparatively to a certain degree (CAMPONÊS DO BRASIL, 2016).

International Relations of the Middle East and the Arab World at UFRGS

The argument developed in this section is that destabilizing the Middle East discourse as a zone of perennial conflict in university classrooms requires direct and systematic interventions by academics entitled with the task of teaching Arab and Middle Eastern studies, both regarding the way the courses are constructed and the choice of the bibliography to be consulted. It is also argued that a specific focus on intra-Arab relations allows for more frequent use of concepts such as "cooperation", "development", "culture" and "Global South", which contributes to a more positive and empathetic look by students towards that space of the world inhabited mainly by peoples who identify themselves as Arabs and Muslims.

The Graduate Program in International Strategic Studies (PPGEEI) initiated its activities in 2011. During its first eight years of existence, eighty-five Master's dissertations and fifty Doctoral theses were defended. Of this amount, only nine dissertations had the Middle East (ME) or the Arab World (AW) as their subject matters, including individualized country studies. This small number of dissertations included at least three on Brazilian foreign policy to the Middle East or Arab countries, one on Afghanistan (a country whose inclusion in this list is questionable), one on United States (US) foreign policy to the Middle East, two on Iraq and two on Syria. Except for the cases of Brazilian foreign policy studies for AW/ $\mathrm{ME}$, almost all of these dissertations dealt with crises, conflicts and wars. No Doctoral thesis on the AW/ME has been defended since the foundation of the PPGEEI. It is difficult to understand how the Arab World, the third largest destination of Brazilian global exports, after only China and the United States, arouses so little interest in the PhD students of this program. When we make explicit the fact that the flow of Arab-Brazilian 
trade exceeds US\$ 19 billion per year (CÂMARA DE COMÉRCIO ÁRABE-BRASILEIRA, 2019) and that there are at least 11 million Brazilians of Arab descent living in the country (VIANA, 2020), this indifference seems even more troubling. This is not to suggest that trade flows or diaspora communities are the only elements to take into consideration when making up the choices of research topics in International Relations (IR), but they are not irrelevant data to be overlooked either.

In the first semester of 2019, a course was taught at the PPGEEI with the specific title of "International Relations of the Arab World". The objective of the professor responsible for the course was to build a differentiated perspective for the so-called Middle Eastern studies. She did so by first defining a new regional dimension to work with (the Arab World, instead of the Middle East), and then focusing on the social, political, economic and cultural dynamics that constitute the Arab region and its relations with the global North and South. Security issues were included in the syllabus, but they were taken out of the spotlight. In other words: crises, conflicts and wars involving Arab countries since the beginning of the 20th century have not been excluded from the program, but they were not the central focus of the course, as usually is the case in Middle Eastern studies. In addition, students were asked to write papers (in pairs) avoiding the reification of the Arab region as a zone of perennial conflict (although writing about conflicts was not forbidden). When writing their papers, they were also invited to avoid, wherever possible, themes revolving around regional conflicts or "proxy wars", where Arab actors are presented as mere puppets in the hands of the so-called global powers.

In the first round of presentations of the proposed articles, in the fifth week of class, the limits of the conception of a course centred on the International Relations of the Arab World with a less bellicose character were evident. Firstly, four classes of three hours each (therefore 12 hours) did not seem to be enough to make graduate students understand what constitutes an Arab political-cultural subject and what constitutes an Arab region, especially in its differentiation from the Middle East or the Mediterranean. At least half of the initial paper proposals submitted by students had Israel and Iran as objects of study. It is noteworthy that not once was Turkey mistaken for an Arab country (as Israel and Iran often are), and that Turkey's location in the world is debatable only in terms of Europe, the Mediterranean, Asia and to a lesser extent the Middle East. Turkey's participation in North Atlantic Treaty Organization (NATO) is perhaps the most prominent feature in the eyes of International Relations/ International Strategic Studies students, resulting in the non-questioning of the non-Arabness of the Turks.

In the tenth week of the course, a second round of discussions on the proposed papers was held. By that time, the conceptual boundaries - and the implications of building these identity boundaries for IR and area studies - between Arabs, Iranians, Persians, Muslims, Turks, Jews and Israelis were already clear. Nonetheless, the focus on regional power disputes, especially involving non-Arab actors, did not change. The hostile relations between Iran and Saudi Arabia seem to exert a special fascination on students, who understand these relations to be fundamentally mediated by 
the opposition between Sunnis and Shiites. At the end of the semester, in the fifteenth class (totaling 60 hours/class), the final versions of the proposed papers were delivered and the themes covered by them were exactly the ones that follow: the smuggling of migrants in Libya and the European geopolitical dispute; the military industrial defense complex in Egypt; the dispute of narratives between Al-Jazeera and Al-Arabiya; the Middle East visions of Al-Jazeera; oil as a link between South Sudan and China; the Chinese-Saudi strategic rapprochement mediated by the convergence of the Saudi Vision 2030 and the Belt and Road initiative; the "proxy war" in the context of Saudi intervention in Yemen; the Saudi quest for power in the Middle East; and Hezbollah as a foreign policy tool of Shiism/Iran.

While the themes are pertinent and appropriate for a course on the Arab World taught in a graduate program in strategic studies, it is essential to note that the professor responsible for the course insisted that the topics covered by the papers avoided as much as possible security issues, and that students were invited to make a conscious effort to explore spaces for intra/inter-Arab cooperation, issues of Arab economic development, and the increasingly active participation of social movements in the Arab political scene. However, it seems that the place assigned to the Arab World by the world centers of knowledge production both in International Relations and Middle Eastern studies is accepted with little or no criticism by Brazilian students. And this is certainly constitutive (note that no causal relationship is being inferred here at all) of the difficulties Brazil faces in expanding bilateral trade and establishing more complex forms of strategic relations with its Arab partners, whether in the areas of social technology transfer, educational exchanges, and the development of joint research to solve or mitigate costly problems for both Brazilian and Arab peoples, such as desertification, food security, and water management, for example.

At the undergraduate level, the opening to "other" (and not "new") themes is facilitated by the way Middle Eastern studies are integrated into the IR curriculum. Firstly, International Relations of the Middle East is not exactly a course of the IR program at UFRGS, but an optional module that falls under the umbrella of Thematic Seminars and is only taught to the extent that a professor is willing to teach the course and the coordination agrees that the course needs to be taught. It is a delicate balance that has been maintained since 2018, the first year that the International Relations of the Middle East was taught as an undergraduate module at UFRGS.

At the first class, it becomes clear that students enroll in the course because they want to "know more" about the Middle East and the expectation of the kind of "more knowledge" that can be built in the classroom is certainly different from that of the PPGEEI. The professor in charge of the course during the two semesters it was offered (2018/01 and 2019/01) began each semester by asking what the students already knew about the Middle East and what they would like to know more about it. The answers were those expected: they know that there is a problem between Israel and "the Arabs"; they know that the Gulf monarchies are rich in oil, but that most of the region is poor; they know that there is a desert that divides North Africa from sub-Saharan Africa; they know that Iran is developing an atomic weapon and that this can be a problem; they know that women are oppressed by Islam; and they know, of course, that there 
is a war against global terrorism, that its epicenter is the Middle East, and that the United States is leading that war. Unsurprisingly, these were exactly the topics that they wanted to know more about.

The professor then suggests building a course that reverses the logic on which these naive knowledges are based, in the language of Paulo Freire (FREIRE, 1968, 1996). The proposed course therefore a) aims to overcome the criticism on the extravagant spending of the Gulf oil monarchies and to focus on the various development funds and banks they maintain that promote development in the Arab World, Africa and Asia; b) suggests discussing the causes of poverty in the region, investigating the colonial origins of this poverty, but also analyzing the efforts of post-colonial states to overcome underdevelopment; c) seeks an analysis of the Sahara not as a barrier between North and South Africa, but as a bridge linking the continent and, within this perspective, drawing attention to Arab-African cooperation via summits held between the Arab League and the African Union; d) proposes to work on the Iranian nuclear program within the terms of racism in global politics and how the terms defining which states are able or not to handle nuclear weapons are highly racialized; e) invites students to center the debate on gender issues in the Middle East on Islamic feminist movements, moving Muslim women from the position of victims in which they are usually placed by the media (a view that is internalized by students) and demonstrating how they stand up to, negotiate, and resist patriarchy; f) proposes the comprehension of the logic and rationality of terrorism of both non-state groups and established states; $\mathrm{g}$ ) rejects the construction of the discipline in the form of an evolutionary historical trajectory that begins in the World War I and ends with the War on Terror and proposes instead the study of thematic units built around the themes of differentiated state formations, the construction of national and supra-national identities, the search for development, South-South cooperation, and also regional conflicts ${ }^{4}$.

The students accept the terms of the new methodological proposal and engage in the development of works that concentrate on such themes as the construction of Palestinian resistance; the foundations, performance and meanings of the Arab League; the new international perspectives of Saudi Arabia under the reign of Mohammed Bin Salman; Shiite political Islam; the Armenian diaspora in the United States; comparative studies between Turkish and Iranian secularism; the Westernization of Muslim fashion; post-colonialism and identity formation in the Arab World; Kurdish women's forms of resistance; the World Cup in Qatar; television media in the Arab World; Palestinian voices in Brazil; Saudi Arabia's Vision 2030; the perception of Porto Alegre's Jewish community about Israel; contemporary Arab cinema; and Queer resistance to Islamic State of Iraq and Syria (ISIS).

The greater openness of IR undergraduate students at UFRGS to other perspectives on the AW/ME and the relative reticence of the PPGEEI's students to these alternative worldviews may be due to the fact that undergraduates feel less pressured than graduate students to produce "relevant" knowledge. As dictated by the rules of Orientalism, this kind of knowledge seeks more to explain "what went wrong" in the Middle East ${ }^{6}$ than to understand how the peoples of the region constitute themselves as subjects of their own history.
4. This suggested program was one way - among various possible ways - the professor (one of the authors of this paper) found to approach Middle Eastern/Arab World studies differently. However, this should not be seen as reminiscent of a political correctness agenda. Moreover, the author understands the pressing need for discussing the ethical aspect of criticizing agendas put forward by the so-called Western powers and at the same time using instruments promoted precisely by these very powers (governmental and non-governmental international organizations or financial bodies, for example) in order to set public and security agendas worldwide.

5. See Lewis (2002).

6. For a critique of who/what determines what is legitimate knowledge in the Social Sciences in general and IR in particular see Mignolo (2002); Alatas (2003); Connel (2012); Tickner (2003). 
7. The concept of the "clash of civilizations" was not created by the Harvard professor Samuel Huntington, but based on a previous article by Bernard Lewis, published three years earlier, The roots of Muslim rage. The Atlantic Monthly, n. 266, September 1990. In 1996, Huntington consolidated his theory in the book The Clash of Civilizations and the Remaking of World Order. New York: Simon \& Schuster, 1996

8. In Arabic dhimmi, or Ahl al-dhimma, refers to the "protected peoples", as described in the paragraph above.
Arab history teaching and research at USP

In July-August 2006, the Arabic Language, Literature and Culture course of the University of São Paulo (USP) decided to inaugurate the two disciplinary fields of Arab History and Philosophy, until then completely absent from the University of São Paulo. The context at that moment, which impacted heavily over several of the university's Arabic professors of Lebanese origin, was the Israeli invasion and bombing of the south of that country. The idea was that the best, possibly the only, means to contribute to a less stereotyped view of the Arabs in the local press, was to promote knowledge. The development of the field of Arab History was expected to help answer the frequent demands from the media - and distortions - that had grown exponentially since 9/11. The understanding of Arab history should help to explain that fundamentalism was not part of any a-historical Arabic nature or eternal Islamic character, but, rather, a specifically modern phenomenon, with its origins, causes, and main locations.

Given the growing influence of the theory of the "clash of civilizations", elaborated by Samuel Huntington in an extensive article in Foreign Affair (HUNTINGTON, 1993) - where he stated that world conflict would from then on be determined by irreconcilable cultural differences, mainly between Muslims and Christians or the so-called "Judeo-Christian civilization" - it was important to treat the relations between Muslims, Christians, and Jews, in an historical and in-depth manner. Throughout the history of the Arab-Islamic caliphates, moments of communal tensions did occur, and some controversy does exist in regard to modes of taxation, among other norms and regulations, but there is no register of systematic persecution against Christian or Jew for the sole reason of their religious or cultural origins. Far from the misleading idea of a menacing empire, Islamic political-administrative structure was built on the basis of the institutionalization of tolerance in regard to the so-called "peoples of the book", that is, those who shared common biblical roots, derived from supposedly the same divine revelation, attributed to the same God. The mode of government orchestrated by the Arabs under Islam, made coexistence possible between religious groups considered unequal, thus being viewed as an historically advanced model for the period in which it was formed (seventh century A.D.), even if absolutely insufficient for current days in which the most radical equality between peoples would be required. The exercise of tolerance in regard to different religious groups was not however an Arab invention. It had been a common practice under the rule of Persian shahs, who did not expect their Cristian, Jewish, or pagan subjects to convert to Zoroastrianism. But under Arab and Islamic rule the institutionalisation of tolerance in relation to those considered dhimmis - with all its limitations - was consolidated as a mode of government. Religious tolerance played a crucial role in the subsequent intellectual and scientific development, from the eighth to practically the twelfth century A.D. The first Arabic translators of the Greek philosophic manuscripts were Christians, such as Husayn Ibn Ishaq, in the IX century. In Al Andalus, more than tolerance per se, there flourished a rich symbiosis between Muslim, Jewish and Christian culture. 
It has been well established that the almost 800 years of Arab presence in the Iberian Peninsula contained a long period of unprecedented cultural flourishing, that left humanity an important precedent of coexistence and legacy in terms of philosophical, scientific and literary texts. It is also well known that the Jewish philosopher Maimonides wrote his main treaties in Arabic. However, some authors would prefer to view $A l$ Andalus as the exception to the rule, rather than to historically explain its decline. For reasons that vary, some tend to look back at the Arabs in a teleological manner, attributing, for example, the lack of democracies among the Arab countries today, to an allegedly backward, authoritarian, and violent nature. For others, more sophisticated one must admit, the question that arises is that which was condensed by Bernard Lewis (2002) in the title of his above mentioned book What Went Wrong? In both cases, however, the argument stems from the view that the Arabs had been unable or unwilling to modernize.

The idea of a certain "Arab incapacity to modernize" reveals an ideological construction that intentionally ignores the political and administrative ottoman reforms of the nineteenth century, islamic reformism a few decades later, and the Arabic literary movement that grew at the turn of the twentieth century mainly in Beirut and Damascus (all of which are topics discussed in the second semester of the Arab history course), as well as the various intellectual tendencies in dispute in the main Arab countries of the Middle East throughout the twentieth century, centered around Marxism, nationalism, and fundamentalism. It also ignores the foreign domination, and local political forces, sometimes in dispute, others in governing alliances. Finally, it ignores that which the murdered historian and journalist Samir Kassir states clearly in his book The Arab Disgrace (KASSIR, 2006), i.e. that the nahda9, or that which he chooses to call "modernity" among Arabs, was very much alive and active up until the 1970s. Had the Lebanese author been alive at the time of the 2011 uprisings, he would have had quite a bit to say about the rebirth of the nahda, even if only to once more explain its defeat and suppression in face of the authoritarian tendencies of the nationalist tradition (as with the military in Egypt or the Baath in Syria) or fundamentalist, such as ISIS or the different groups supported by Saudi Arabia, and acting throughout the region.

It is not our intention, nor would it be possible, to discuss here all the topics covered by the Arab history program, which begins in the pre-islamic period, and makes its way up to the beginning of the twentieth century. As for the disciplines of Modern Palestinian History, The History of Modern Egypt, and Arab Nationalism, they cover the XIX-XX centuries, and focus on specific regions of the Middle East. The Arab history program was conceived to allow the students to acquire basic and fundamental knowledge, such as understanding different timeframes, managing the periods in Arab and Islamic history, understanding the historical relations between the Arabic language and Islam, between religion and politics from the every origins of the $u m m a,{ }^{10}$ Arab expansion, cultural flourishing, nineteenth century reformism, the local answers to colonialism, up to the origins and rise of fundamentalism in the nine-
9. In Arabic, awakening.

10. In Arabic, "community of destiny" or "community of faith", e.g. the community built by Muhammad and his successors, of those who embraced or accepted Islam. 
11. In Arabic, most commonly translated as catastrophe, although the term refers to a human feeling of deep misery.

12. In lídiche, meaning the small Jewish villages of the Czarist pale of settlement (approximately current-day Lithuania, parts of Poland, Belarus and Ukraine).

13. The field of Philosophy in the Arabic course is led by professor Attié Filho, and to understand some of the work developed in that field at the University of São Paulo (ATTIÉ FILHO, 2002). teenth to twentieth centuries. At the same, we discuss some of the basic concepts in Arab history, that are peculiar to the Arabic scenario, and can only be understood in that context. The program, however, soon began operating on a different level. While building a corpus of knowledge among students who had never before studied any Arab history, it also, inadvertently, deconstructed a considerable amount of accumulated stereotypes - as if two parallel programs were developed, one explicit, and the other, resulting from the critical assessment of the subject proposed.

In slightly more than a decade since the beginning of the Arab history program, we have realized that the undergraduate students could identify, almost intuitively, some of the narratives linked to domination and colonialism, reproduced either in the media or in history texts. Accordingly, we have never faced any special difficulty when working with the students on the more specific, and possibly more polemic, bibliography related to the history of Palestine. On the contrary, we have had typically excellent discussions on the meaning of the nakba", and of the most recent historiographic advances in the field, in classrooms of 50, 60, or more students from all over campus, and not only from the Arabic course. This discipline begins analysing nineteenth century ottoman and mainly rural Palestine, then shifts over to nineteenth century Europe to study anti-Semitism, and the conditions of the Jews in the shtetle $e^{12}$ of the Czarist pale of settlement, out of which Zionism would grow as one of the movements proposing emancipation. Then back to Palestine again. That is, the subject is dealt with in a manner that includes, and does not erase its inherent complexities.

With the undergraduate students, we also discuss Eurocentric periodization, which divides history into ancient, medieval, modern and contemporary periods, or classifications related to economic (feudalism) and cultural models (renaissance), that not only do not take Arab history into account, but in some cases exclude it. The renaissance, for example, is usually studied as an exclusively European process in history, in spite of the role played by Arabic philosophical texts - both translations of texts from ancient Greece, and treaties written by the most important Arab philosophers of the time. ${ }^{13}$ When Saint Thomas Aquinas began reading Aristotle, he did so initially through the lens of the writings of Ibn Sina. Throughout the "Middle Ages", the Arabs not only "preserved" but developed the knowledge transmitted through the ancient Greek texts. As stated by Jack Goody (2008), the so called European renaissance would be better understood, not as the outcome of classical Greek culture, but as the continuation of cultural development in Islam as in China, regions which were extremely advanced, socially and culturally in that period of time. The perception, on the part of the students, of the profound European ethnocentrism implicit in the theoretical corpus and basic concepts of History, opens the path for a paradigmatic shift, which begins with the perception that development is not an exclusively European movement (from Greek civilization to the advent of capitalism, in a manner that excludes non-Europeans from civilizational progress) and leads all the way to the deconstruction of the idea of a world divided between East and West. 
However, the systematic study of the critique of orientalism is conducted in the graduate studies program. As a result, in 2016 an edition of Tiraz, the magazine of the Program of Graduate Arabic and Jewish Studies, was published with a selection of texts written by the students (TIRAZ, 2016). The articles demonstrated how these young researchers were already applying the theoretical and conceptual framework of the critique of orientalism to their research, as demonstrated not least by the topics chosen to investigate, but also the selection, and treatment of their sources. From the point of view of Brazilian researchers, the critique of nineteenth century European orientalism relates, in historical terms, to the ethnocentrism that accompanied and justified, three hundred years earlier, the domination of the indigenous peoples of America (WALLERSTEIN, 2007), and, in current days, to the position on the margins of the developed world which we (scholars in Brazil and Arab countries) certainly seem to exercise in common.

But difficulties do tend to occur when we receive graduate degree candidates who have not attended the Arabic course, or, in some cases, are not trained historians. The researcher of Arab history must be trained in both Arabic language and the methods of History - a long process which should ideally be initiated as an undergraduate student. Today, our Masters candidates have only two years to complete their thesis, and the $\mathrm{PhD}$ candidate, four. The time span in both cases is not nearly enough if the candidate lacks one or another basic formation. The lack of adequate training may also reveal itself in a tendency to reproduce, a-critically, misguiding concepts and views, present in so many of the texts available. The thesis advisor certainly has double the responsibility when this happens, and should be aware of how frequent it is for young researchers of Arab and Islamic history to end up with an ideologically tainted work, be it under the influence of the theory of the clash of civilizations/orientalism, be it under the influence of a militant pro-Arab standpoint - to mention but the extremes. The process of deconstructing the highly stereotyped view of the Arab World is not intended to generate its diametric and extreme opposite, but, on the contrary, to generate the conditions in which research in Brazilian universities may actually take advantage of the absence of the mode of imperialist designs which marked the birth of academic studies of the Arab Middle East, and still largely determine current relations with the Muslims of Europe.

Finally, our student mobility to and from the Arab universities is still very timid, but a couple of academic exchange agreements have allowed our students to complete their Arabic language studies, mainly in Egypt, but also Morocco and Oman. The agreement we had with Al Quds University, Palestine, did not work due to the fact that Israel does not concede student visas for those applying for Palestinian universities, but other agreements should make up for that unprecedented setback. To complete his or her formation at universities in an Arab country, where our students will be able to experience the culture, the dilemmas of the different, although in so many aspects, comparable world views, is a very desirable and fruitful encounter. 
Conclusion

A comparative approach to the experiences narrated above, in two of the largest Brazilian universities, revealed that students' interests in the AW/ ME related topics is not substantial and might be growing in quite the wrong direction under the inevitable influence of the North American security approach. The limitations in both size and capacity of these programs are to a great extent due to the lack of funding and to the virtual absence of stimulus for the development of exchange programs between faculty and students on both sides of the Atlantic. Arab embassies in Brazil have shown virtually no interest in promoting such exchanges, and Brazilian universities have also faced limited capacity to fund programs that could build knowledge and develop fields of intellectual, economic and social interest among Latin America and the Arab World - regions that are actually so close to each other.

With an estimated population of at least eleven million citizens of Arab descent, Brazil is home to the largest population of Arabs outside the Arab world. The members of the League of Arab States, together, represent the third largest destination for Brazilian world exports. The Arabic language has long been spoken in Brazil, beginning during the period of slavery when thousands of Muslims capable of communicating in Arabic were brought to the country as slaves. It then reached its peak with the massive immigration of Christian Arabs to Brazil at the beginning of the twentieth century. Brazil's trade balance with Arab countries has been favourable to Brazil for a long time, even in the case of the big oil exporting countries. Brazilian exports of manufactures - from refrigerators to cars, buses and airplanes - find in the Arab market important partners for high added value South-South trade.

As this article demonstrated, the socialisation of Brazilian scholars in the Anglo-Saxon literature on the Middle East must be mediated by a critical posture towards any parochial knowledge that pretends to be global. This critical positioning is a pre-requisite for them - for us - to evolve from mere reproducers of the discourses produced in the North about the region to actual thinkers of the Global South capable of offering their - to our students a space of knowledge production from our place in the world. It also showed that destabilizing the Middle East discourse as a zone of perennial conflict in university classrooms requires direct and systematic interventions by academics entitled with the task of teaching Arab and Middle Eastern studies, both regarding the way the courses are constructed and the choice of the bibliography to be consulted. As it was seen, however, sometimes this has proven not to be enough. As shown comparatively, by the above related classroom and research group experiences, one might find it necessary to actually instigate debates around the question of representation, particularly media, literary, and historiographic representations. Finding commonalities between Eurocentric or other ethnocentric representations of both "the South" and "the East" has proven to be a very stimulating process, one capable of highly engaging the students, and promoting important avenues for open-end learning in terms of critical thinking.

Ultimately, the Brazilian academic community must be continuously reminded that colonialism, imperialism and wars are not part of the history of Brazil's relations with the Arab World. Therefore, why should Brazilian 
students follow the Anglo-Saxon textbooks, curriculum and syllabi on the Middle East, unremarkably stuffed with wars, battles, and other domestic or international conflicts, most of them consequence of the very relationship of this region with the old and new colonial powers? It would be more productive for Brazilian students to get to know those peoples who have been developing peaceful and cooperative relations with us for decades - if not centuries. And these peoples are Arabs, and to know the historical process that constitute them as Arabs and how they relate to the world in general, and to the Global South - Latin America and Brazil in particular - i.e., to our students' place of belonging in the world is essential for the development of deeper and more comprehensive relations between Brazil and the Arab World.

$$
\text { References }
$$

ALATAS, Syed F. Academic dependency and the global division of labour in the social sciences. Current Sociology, v. 51, n. 6, p. 599-613, 2003

AMADO, Jorge. A Descoberta da América pelos Turcos. São Paulo: Companhia das Letras, 2008.

ATTIÉ FILHO, Miguel. Falsafa, a Filosofia entre os Árabes. São Paulo: Palas Athena, 2002.

CAMPONÊS DO BRASIL, Bruno. Meta-academia: como as instituições acadêmicas brasileiros estudam o Oriente Médio. In: VASCONCELOS, A.; CLEMESHA, A.; GUIMARÃES, F. Brasil e o Oriente Médio: o poder da sociedade civil. São Paulo: IRI-USP, 2016, p. 140.

CAMARA DE COMÉRCIO ÁRABE-BRASILEIRA. Câmara de Comércio Árabe-Brasileira. Balança Comercial Brasil com Países Árabes: janeiro a dezembro de 2019. São Paulo, 2019. 13 slides, color. Available at: https://anba.com.br/wp-content/uploads/2019/07/BC-Junho-2019. pdf. Accessed: 20 jun. 2020.

CLEMESHA, Arlene. História Árabe, Disciplina Acadêmica e Visão de Mundo. Tiraz: Revista de Estudos Árabes e das Culturas do Oriente Médio, ed. 8, p. 68, 2016.

CONNELL, Raewyn. A iminente revolução na teoria social. Revista Brasileira de Ciências Sociais, n. 80, p. 9-20, 2012.

DAVISON, Roderic H. Where Is the Middle East? Foreign Affairs, v. 38, n. 4, p. 665, 1960.

FERABOLLI, Silvia. Arab Regionalism: a post-structural perspective. 2. ed. Abingdon: Routledge, 2015.

FREIRE, Paulo. Pedagogia da Autonomia: saberes necessários à prática educativa. São Paulo: Paz e Terra, 1996.

FREIRE, Paulo. Pedagogia do Oprimido. São Paulo: Paz e Terra, 1968.

GOODY, Jack. O Roubo da História. Como os europeus se apropriaram das idéias e invenções do Oriente. São Paulo: Contexto, 2008.

HUNTINGTON, Samuel. The clash of civilizations? Foreign Affairs, n. 72, p. 22-49, summer 1993.

KASSIR, Samir. Considerações sobre a Desgraça Árabe. Lisboa: Cotovia, 2006.

LEWIS, Bernard. O Que Deu Errado No Oriente Médio? São Paulo: Zahar, 2002.

MIGNOLO, Walter. The geopolitics of knowledge and the colonial difference. The South Atlantic Quarterly, v. 101, n. 1. 2002. p. 57-95.

TICKNER, Arlene. Seeing IR Differently: Notes from the Third World. Millennium: Journal of International Studies, v. 32, p. 295-324, 2003.

Tiraz: Revista de estudos árabes e das culturas do Oriente Médio, n.8. São Paulo: FFLCH-USP, 2016.

VIANA, Diego. Cooperação diplomática ajuda a promover o comércio. Valor Econômico, October 10, 2020. Available at: https://valor.globo.com/publicacoes/suplementos/noticia/2020/10/26/ cooperacao-diplomatica-ajuda-a-promover-comercio.ghtml. Accessed: 22 nov. 2020.

WALLERSTEIN, Immanuel. O Universalismo Europeu: a retórica do poder. São Paulo: Boitempo, 2007. 